\title{
EXTRATERRITORIAL RIGHTS AND CONSTITUTIONAL METHODOLOGY AFTER RASUL $V$. BUSH
}

\section{GERALD L. NEUMAN ${ }^{\dagger}$}

Professor Roosevelt's thoughtful article reviews the evolution of doctrine concerning the extraterritorial application of constitutional rights, identifies Rasul v. Bush ${ }^{1}$ as marking an opportunity to rethink prior debates, and sketches a new approach to the problem derived from the conflict of laws. ${ }^{2}$ Roosevelt's analysis engages generously, while critically, with my own work on this subject. Although our starting points differ, we agree about many things, including the fact that new solutions could be useful. Nonetheless, I have deep reservations about a conflicts-based approach, as I will explain in this response.

Regarding the implications of the jurisdictional decision in Rasul for future litigation on the merits, I agree that the majority opinion strongly suggests in a footnote that foreign nationals in U.S. custody at Guantanamo Bay Naval Base ("Guantanamo") possess constitutional rights. ${ }^{3}$ I agree that the opinion leaves ambiguous the reason why foreign nationals have constitutional rights there-whether because they are human beings in long-term U.S. custody or because of the special character of U.S. authority at Guantanamo. And I agree that the answer for the present is more likely to turn on features peculiar to Guantanamo than on a general exploration of extraterritorial due process. In the words of Justice Kennedy's Rasul concurrence, "Guan-

${ }^{\dagger}$ Herbert Wechsler Professor of Federal Jurisprudence, Columbia Law School.

124 S. Ct. 2686 (2004).

2 Kermit Roosevelt III, Guantanamo and the Conflict of Laws: Rasul and Beyond, 153 U. PA. L. REV. 2017 (2005).

${ }^{3}$ The footnote reads:

Petitioners' allegations-that, although they have engaged neither in combat nor in acts of terrorism against the United States, they have been held in Executive detention for more than two years in territory subject to the long-term, exclusive jurisdiction and control of the United States, without access to counsel and without being charged with any wrongdoing-unquestionably describe "custody in violation of the Constitution or laws or treaties of the United States.” 28 U.S.C. \$2241(c)(3). Cf. United States v. Verdugo-Urquidez, 494 U.S. 259, 277-78 (1990) (Kennedy, J., concurring), and cases cited therein.

Rasul, 124 S. Ct. at 2698 n.15. The reference to Justice Kennedy's concurring opinion in Verdugo clearly indicates that the defect is constitutional, not statutory or treatybased. 
tanamo Bay is in every practical respect a United States territory," ${ }^{4}$ although the United States lacks formal sovereignty there. In one sense, however, a location-specific holding would not provide the "narrowest" ground of decision. Treating the enclave as tantamount to a territory should entail that the rights of foreign nationals there are comparable to their rights in overseas territories such as Puerto Rico or Guam, a fuller set of rights than foreign nationals could claim in wholly extraterritorial locations.

Even so, the question of extraterritorial rights remains important after Rasul, both within and outside the context of counterterrorism efforts. If the government blundered by bringing its captives to Guantanamo, it may rely more heavily in the future on other, more authentically extraterritorial venues for detention. ${ }^{5}$ The government may also relocate its operations for maritime enforcement of U.S. immigration laws against refugees, economic migrants, and smugglers. ${ }^{6}$ From a general doctrinal perspective, the Rasul majority insisted on interpreting the dated precedent of Johnson $v$. Eisentrager ${ }^{7}$ in accordance with Eisentrager's holding and context rather than give force to all its broad-ranging dicta. This more accurate assessment of Eisentrager provides an apt occasion for reexamining the geographical reach of constitutional limitations.

\section{The GEOGRAPHICAL SCOPE OF U.S. CONSTITUTIONALISM}

Professor Roosevelt and I largely agree about the history of doctrinal evolution concerning extraterritorial constitutional rights, and I will not repeat the narrative here. By the twentieth century, one cru-

\footnotetext{
${ }^{4}$ Rasul, 124 S. Ct. at 2700 (Kennedy, J., concurring). For a detailed discussion of the similarity between Guantanamo and earlier nonsovereign territories of the United States, such as the Panama Canal Zone and the Trust Territory of the Pacific Islands, see Gerald L. Neuman, Closing the Guantanamo Loophole, 50 LOY. L. REV. 1, 15-42 (2004).

${ }^{5}$ See, e.g., Dana Priest, Memo Lets CIA Take Detainees Out of Iraq, WASH. Post, Oct. 24, 2004, at A1 (noting that "[s]ince the Sept. 11, 2001, attacks, the CIA has used broad authority granted in a series of legal opinions and guidance from the Office of Legal Counsel and its own general counsel's office to transfer, interrogate and detain individuals suspected of terrorist activities at a series of undisclosed locations around the world"); cf. United States v. Moussaoui, 382 F.3d 453, 464 n.15 (4th Cir. 2004) (noting that the government declined to confirm or deny facts concerning the custody of particular detainees with potentially exculpatory information).

${ }^{6}$ See Neuman, supra note 4, at 42-43 (describing the use of Guantanamo as a detention site in migrant interdiction operations).

${ }^{7} 339$ U.S. 763 (1950). For criticism of the Eisentrager dicta and their later use, see Neuman, supra note 4 , at 49-50, 54-65.
} 
cial proposition, from which we both proceed, was settled: the Constitution as a whole applies everywhere, and is the source of U.S. government power, although particular provisions might have more limited reach. ${ }^{8}$ Congress derives its authority from Article I (supplemented by other provisions and implications), whether it acts with domestic or extraterritorial effect. The President derives his authority from Article II, whether he acts with domestic or extraterritorial effect. " $[\mathrm{T}]$ he Government may act only as the Constitution authorizes, whether the actions in question are foreign or domestic." ${ }^{10}$ That proposition, however, does not itself resolve what the Constitution authorizes or forbids. The question remaining to be answered is the scope of particular provisions limiting those powers, in particular whether provisions of the Bill of Rights apply to the benefit of citizens or aliens outside U.S. territory.

To frame the discussion, it would be useful to distinguish among three approaches to the extraterritorial scope of constitutional rights, each visible in the various opinions in the Supreme Court's 1990 decision in United States $v$. Verdugo-Urquidez, ${ }^{11}$ before contrasting them with Roosevelt's proposed fourth approach.

The first is the approach apparently taken by Chief Justice Rehnquist in his opinion (essentially for a plurality) in Verdugo. ${ }^{12}$ In this model, U.S. citizens have extraterritorial constitutional rights and

${ }^{8}$ See Roosevelt, supra note 2, at 2034 (stating the views of Justice White, which Professor Roosevelt implicitly accepts in his analysis).

${ }^{9}$ Justice Sutherland's contrary view expressed in United States v. Curtiss-Wright Exp. Corp., 299 U.S. 304, 318 (1936), that the President exercises extraconstitutional powers of external sovereignty, has been greatly criticized, and the Court has more commonly engaged in broad construction of the President's power under Article II. See, e.g., Am. Ins. Ass'n v. Garamendi, 539 U.S. 396, 414-15 (2003) ("[T] he historical gloss on the 'executive Power' vested in Article II of the Constitution has recognized the President's vast share of responsibility for the conduct of our foreign relations." (internal quotation marks omitted)).

${ }^{10}$ United States v. Verdugo-Urquidez, 494 U.S. 259, 277 (1990) (Kennedy, J., concurring).

${ }^{11} I d$. at 261 (opinion of Rehnquist, C.J.); id. at 275 (Kennedy, J., concurring); id. at 279 (Brennan, J., dissenting); id. at 297 (Blackmun, J., dissenting).

${ }^{12}$ See id. at 263-74 (opinion of Rehnquist, C.J.). I say "apparently" because the opinion is internally contradictory; I characterize it as essentially a plurality because Justice Kennedy ostensibly provided the fifth vote, while adopting quite a different approach in his concurring opinion. See GERALD L. NEUMAN, STRANGERS TO THE CONSTITUTION: IMMIGRANTS, BORDERS, AND FUNDAMENTAL LAW 105-07 (1996). Much of the opinion is dictum, and the holding relates only to Fourth Amendment rights of nonresident aliens. See Verdugo, 494 U.S. at 261, 274-75 (holding that the Fourth Amendment does not apply "to the search and seizure by United States agents of property that is owned by a nonresident alien and located in a foreign country"). 
foreign nationals do not. Even as to citizens, the Bill of Rights does not apply fully and literally overseas, as Justice Black's plurality opinion in Reid $v$. Covert had maintained, ${ }^{13}$ but only partially and contingently, as Justices Frankfurter and Harlan argued in their concurrences. ${ }^{14}$ Aliens, meanwhile, "can derive no comfort from the Reid holding."

The second alternative comes from Justice Kennedy's concurring opinion in Verdugo, building differently on Harlan's methodology in Reid v. Covert. ${ }^{16}$ For both citizens and aliens, a contextual, due-processstyle analysis would inquire "which guarantees of the Constitution should apply in view of the particular circumstances, the practical necessities, and the possible alternatives," and whether conditions would "make adherence to a specific guarantee altogether impracticable and anomalous." ${ }^{17}$ As the narrowest explanation of the holding in Verdugo, this "global due process" approach enjoys precedential support. Nonetheless, the global due process approach has not yet acquired an academic theorist who would elaborate and defend it as the best interpretation of U.S. constitutionalism. In the past, I have criticized its unpredictability and lack of textual anchor, although I regard it as normatively superior to Chief Justice Rehnquist's Hobbesian stance. ${ }^{18}$

The third alternative, appearing in the Verdugo dissents, ${ }^{19}$ is what I have called the "mutuality of obligation" approach. I have defended it

\footnotetext{
${ }^{13} 354$ U.S. 1, 5-6 (1957). Although Black wrote for only four Justices in Reid, he acquired majority support in Kinsella $v$. United States ex rel. Singleton, 361 U.S. 234 (1960), and its companion cases. The retreat from full extraterritorial applicability of the Bill of Rights to citizens in Verdugo's dicta therefore came as a surprise.

${ }^{14}$ See Verdugo, 494 U.S. at 270 (referring to Reid, 354 U.S. at 41 (Frankfurter, J., concurring); 354 U.S. at 65 (Harlan, J. concurring)).

${ }^{15}$ Verdugo, 494 U.S. at 270.

${ }^{16} I d$. at 277-78 (Kennedy, J., concurring) (citing Reid, 354 U.S. at 74 (Harlan, J., concurring )).

${ }^{17}$ Reid, 354 U.S. at 74-75 (Harlan, J., concurring) (emphases omitted). Roosevelt suggests that the "global due process" approach might better be classified as resting on a "limited government" theory rather than a "fundamental rights" theory. Roosevelt, supra note 2, at 2042. While some passages in Downes v. Bidwell, 182 U.S. 244 (1901), support such a formulation, see, e.g., id. at 293-94 (White, J., concurring) (noting that "limitations of this character cannot be under any circumstances transcended, because of the complete absence of power"), the "limited government" rationale is too uninformative (as Roosevelt explains), and did not guide the later development of the doctrine.

${ }^{18}$ See Neuman, supra note 12, at 113-16. Given its precedential support, I have also invoked the global due process analysis in amicus briefs.

${ }^{19}$ See Verdugo, 494 U.S. at 284 (Brennan, J., dissenting); id. at 297-98 (Blackmun, J., dissenting).
} 
in my prior work, but I agree that it is not currently the law for foreign nationals. Roosevelt describes this approach fairly in his article. The mutuality of obligation approach presumes that the extension of U.S. constitutional rights accompanies the assertion of an obligation to obey U.S. law, because the framework of rights is designed to legitimate government's claim to obedience. ${ }^{20}$ This correlation between rights and governing authority suggests that constitutional rights should presumptively apply to all persons within U.S. territory, ${ }^{21}$ and to all U.S. citizens in any location, but that extraterritorial rights of foreign nationals presumptively arise only in contexts where the United States seeks to impose and enforce its own law. It would not necessarily follow that application of a constitutional right produces identical results in domestic and foreign locations-either for citizens or for aliens-given that the operative facts and available alternatives may differ. ${ }^{22}$

Since the Verdugo decision, lower courts and commentators have diverged in their efforts to make sense of conflicting implications between the opinions and within the Chief Justice's opinion. Some courts have embraced the view that dicta in Verdugo exclude any constitutional protection for nonresident aliens outside U.S. territory. Most graphically, the D.C. Circuit has held that the Due Process Clause does not protect foreign nationals against torture by U.S. agents abroad. ${ }^{23}$ That decision arose from an internal conflict in Guatemala, and did not treat the distinction between law enforcement and non-law-enforcement contexts as relevant.

Against this background, the search continues for a persuasive account of U.S. constitutionalism that responds adequately to the vastly

${ }^{20}$ See Neuman, supra note 12, at 98-100. The presumption is rebuttable, where the text expressly limits the personal or geographical scope of a right, or where structural arguments demonstrate that the right should not be interpreted as applying. I have defended this approach as an interpretation of the U.S. Constitution, not as a substitute for positive law.

${ }^{21}$ In this context, it is persuasive to regard areas like the (former) Panama Canal Zone and Guantanamo as functionally U.S. territory.

${ }^{22}$ I have argued, for example, that the First Amendment should impose stricter limits on government regulation of association with domestic political organizations engaged in violent activity than on government regulation of association with otherwise comparable foreign organizations, because the U.S. government has less opportunity to control the foreign organizations directly. See Gerald L. Neuman, Terrorism, Selective Deportation, and the First Amendment after Reno v. AADC, 14 GEO. IMMIGR. L.J. 313, 330-31 (2000).

${ }^{23}$ See Harbury v. Deutch, 233 F.3d 596, 604 (D.C. Cir. 2000), rev'd on other grounds sub nom. Christopher v. Harbury, 536 U.S. 403 (2002). 
increased overseas activity of the federal government since the Second World War. A rigidly territorial interpretation of the Constitution would ignore the effects of economic globalization, extraterritorial regulation and law enforcement, and delocalized information technology. At the same time, advances in communications technology have greatly decreased the cost of accommodating extraterritorial rights claims. If a new approach would better reconcile the needs of government and the need to constrain governing power, and could attract a judicial consensus, then it would certainly be welcome.

\section{CAN A CONFLICT-OF-LAWS APPROACH PROVIDE THE SOlUtion?}

I have previously criticized the idea of a conflict-of-laws approach to constitutional interpretation, ${ }^{24}$ but the relevance of those criticisms may depend on a preliminary question: in what sense does Professor Roosevelt's article propose a conflict-of-laws approach?

Talk of a conflict-of-laws approach to the extraterritorial application of constitutional rights immediately raises two concerns. First, it suggests the prospect of a choice between our Constitution and foreign law as the measure of government power over individuals. That prospect is troublesome for several reasons. From the individual's perspective, it might permit the U.S. government to sink to the level of a totalitarian state in exercising authority over foreign nationals or even U.S. citizens in overseas locations. From the U.S. government's perspective, it could have the unacceptable effect of allowing a foreign government to tighten at will constraints on the power of our legislature or executive. Extraterritorial constitutional issues arise when an otherwise valid congressional statute or executive policy applied beyond our borders is challenged as violating a constitutional right. A choice between U.S. and foreign law may make sense in deciding whether or not the congressional statute applies extraterritorially. But once it has been determined that the statute does apply, any clash between the statute and the Constitution must be resolved as a matter of U.S. law and not foreign law. Foreign law does not govern as between the individual and Congress, against the will of Congress. ${ }^{25}$

\footnotetext{
${ }^{24}$ See Gerald L. Neuman, Conflict of Constitutions? No Thanks: A Response to Professors Brilmayer and Kreimer, 91 MicH. L. REV. 939 (1993).

${ }^{25}$ For clarity, I am not contending that foreign law should always be irrelevant to the effective content of constitutional norms as applied to U.S. government action in foreign locations. For example, if the Fourth Amendment applies extraterritorially to the search of a U.S. citizen's person or property, then foreign law may determine what property the citizen owns, and foreign law may be a relevant factor in deciding
} 
Second, a "conflict of laws approach" might make subconstitutional positive law (conflicts rules) control the meaning of constitutional provisions. That would be a dangerous fallacy, because it would invert the hierarchy of norms presupposed by constitutionalism, and would authorize Congress to define the limits of its own power.

But this initial reaction largely mistakes the sense in which Professor Roosevelt is arguing for a conflict-of-laws approach. Roosevelt employs a broader concept of conflict of laws, adapted from Dean Larry Kramer's work, under which "wholly domestic" conflicts between two legal rules of the same jurisdiction may be subsumed in the field of conflicts. ${ }^{26}$ Elsewhere Roosevelt cites the example of federal preemption of state law; ${ }^{27}$ apparently the concept also includes "conflicts" between the Constitution and federal statutes. Like Kramer, Roosevelt argues for a two-step approach to resolving conflict-of-laws issues, with a first step that explores the meaning of the allegedly conflicting norms to see whether they actually cover the case at hand, and a second step that resolves the conflict between them if any remains. Roosevelt calls the first step "scope" analysis and the second step "priority" analysis. ${ }^{28}$

Roosevelt explains that the extraterritorial application of constitutional rights should be decided by means of a "scope" analysis, and that the "priority" step does not arise because there is no potentially applicable foreign law that governs as between the U.S. government and aliens in its custody claiming rights. I agree with the second point, and also with describing the first issue as one of "scope." 29 Roosevelt continues, quoting Kramer, that "the court should determine what policy a law was enacted to achieve in wholly domestic cases and ask'... whether its application to a case with foreign elements will promote its domestic purpose." ${ }^{30}$

whether particular expectations of privacy are reasonable. But foreign law does not dictate the contours of Fourth Amendment protection.

${ }^{26}$ See Larry Kramer, Rethinking Choice of Law, 90 CoLuM. L. REV. 277, 283 (1990); Roosevelt, supra note 2, at 2064-65; Kermit Roosevelt III, The Myth of Choice of Law: Rethinking Conflicts, 97 MiCH. L. REV. 2448, 2489-93 (1999).

27 See Roosevelt, supra note 26, at 2493-98.

${ }^{28}$ Roosevelt, supra note 2, at 2064-65. In an earlier article, he described the two steps as "rules of scope" and "conflicts rule[s]." Roosevelt, supra note 26, at 2467-68.

${ }^{29}$ See Neuman, supra note 12, at 4-5.

${ }^{30}$ Roosevelt, supra note 2, at 2065 (quoting Larry Kramer, Vestiges of Beale: Extraterritorial Application of American Law, 1991 SUP. CT. REV. 179, 213). 
In one sense, who could quarrel with that? Construing a right in light of its purposes sounds like an ordinary method of legal interpretation.

Moreover, to the extent that the methodology of conflict of laws derives from background understandings of the operation of legal systems at a given period, such understandings have in the past informed interpretations of the scope of constitutional provisions. It is not unreasonable that they should do so, as long as this form of interpretation does not permit subconstitutional positive law to dictate the meaning of constitutional provisions. ${ }^{31}$

Nonetheless, I am concerned that Roosevelt's interpretation of the scope of constitutional rights is affected by the starting point in "conflict of laws," and employs assumptions of interest analysis in a manner that might lead the investigation astray.

Given the acknowledged influence of Larry Kramer's methodology, certain features of Kramer's exposition deserve attention. Kramer has described his first-stage inquiry into scope (or "prima facie applicability") $)^{32}$ as involving two components: "(1) ascertaining the purpose that led to the adoption of a law in wholly domestic cases, and (2) presuming that the law applies only when that purpose is advanced in the state." ${ }^{, 33}$ Kramer explains that the second of these components "is unique to choice of law," in that it serves as "a means of accommodating the laws of other states," and that it "depends on the possibility that other laws might also apply." ${ }^{34}$ Kramer assumes that states have an interest in protecting their citizens (or residents) against harmful acts, and in regulating conduct that occurs within their borders. Like many adherents of interest analysis, however, he deemphasizes the state's interest in preventing its own citizens from harming nonresidents outside its borders. In U.S. interstate cases, this neglect may often be justified by deference to a sister state's choices and the opportunity of applying sister-state law instead. But application of foreign law is not an option in the context we are discussing.

Roosevelt's "scope" analysis appears similar to Kramer's in construing the "domestic purpose" of a constitutional right as turning on its benefit in or for the United States, not on its value to rights-holders

\footnotetext{
${ }^{31}$ Some originalists, for example, might object to allowing changing background understandings of a given period to supply meaning to unchanging constitutional provisions-but I am not an originalist.

${ }^{32}$ Kramer, supra note 26, at 291.

${ }^{33} I d$. at 299 (emphasis added).

${ }^{34} I d$. at 301-02.
} 
considered in the abstract or in a context that can be generalized. That interpretive strategy needs to be defended.

The scope analysis also appears to proceed in isolation, clause by clause, rather than within an understanding that the set of constitutional rights share any common purpose. Roosevelt thereby rejects the assumption, which informs the mutuality of obligation approach, that constitutional rights form part of a framework for legitimating the exercise of governing power over individuals. Conceivably this ad hoc examination of each right or clause derives from the habits of conflict of laws, dealing neutrally with unrelated statutes adopted from time to time by legislatures pursuing whatever policies they wish.

Thus, although Roosevelt's proposal avoids the manifest defects of a conflicts process for deciding claims of constitutional right, it retains enough of conflicts thinking to create a risk that interest analysis will deflect constitutional interpretation.

\section{THE EXAMPLE OF FREEDOM OF SPEECH}

The distorting potential of a conflict-of-laws approach appears most clearly when Professor Roosevelt's proposal turns to First Amendment rights to freedom of speech. The analysis begins with an identification of two interests that underlie free speech doctrine: a systemic interest in democracy (or collective self-government) and an individual interest in what he terms "self-actualization." " Roosevelt then argues that aliens' communications from abroad to Americans further U.S. self-government, and so may be protected by the First Amendment, whereas aliens' communications among themselves abroad do not further U.S. self-government, and so are not protected by that rationale. Moreover, he finds it "hard to see why the Constitution would be concerned with the self-actualization of aliens abroad," and argues, therefore, that a "domiciliary focus seems appropriate." Thus, the free speech guarantee of the First Amendment would not apply to nonresident aliens' communications among themselves abroad.

In other words, we have found ourselves back with the "domiciliary focus" endemic to interest analysis. One might agree that the First

\footnotetext{
${ }^{35}$ Roosevelt, supra note 2, at 2066. For readers to whom "self-actualization" connotes egocentric self-indulgence, a different phrasing might be appropriate, but the choice of term does not matter so long as we take it seriously as an interest central to individual moral autonomy.

${ }^{36} I d$.
} 
Amendment does not impose a mandate on the U.S. government to facilitate aliens' self-actualization abroad, but is it so clear that no First Amendment concerns are raised when the government reaches out to crush aliens' self-actualization abroad? It should be emphasized again that excluding nonresident aliens' speech from First Amendment protection does not relegate them to the law of their own domicile, which cannot control U.S. government action, but rather exposes them to whatever prohibitions Congress decides to enact.

To make the issue more concrete, we are now guaranteed a longterm struggle between the United States and terrorists drawn from Muslim populations that are deeply suspicious of U.S. motives. Influencing public opinion in those societies may prove important to national defense. Suppose that the United States attempts to intervene in those societies not only by means of aid and publicity but through extraterritorial criminal laws designed to serve its security interests. Can Congress-or the Executive-make it a crime for foreign nationals in Pakistan, or Indonesia, to criticize U.S. foreign policy to one another, to broadcast videos of Osama Bin Laden, to belong to an Islamist political party, or to "endorse terrorist activity"? Can the United States then enforce such prohibitions against whatever foreign violators fall into its custody?

I believe it is clear that foreign nationals could not be brought to the United States and tried on the mainland for such crimes. That guarantee, consistent with the First Amendment, would be triggered by foreign nationals' presence once brought here to be punished for speech crimes under U.S. law. ${ }^{38}$

Suppose instead that the executive acquires custody of foreign nationals in allied countries, and seeks to try them for these crimes at an

${ }^{37}$ For the latter, see 8 U.S.C. § 1182 (a) (3) (B) (i) (VI) (2000) (denying admission to the United States to, inter alia, prominent aliens who "endorse or espouse terrorist activity ... in a way that the Secretary of State has determined undermines United States efforts to reduce or eliminate terrorist activities").

${ }^{38}$ See United States v. Aguilar, 883 F.2d 662, 684-85, 692 (9th Cir. 1989) (applying First Amendment free speech doctrine in upholding the conviction of a noncitizen for extraterritorial conduct in instructing Central Americans on how to cross the border illegally and seek sanctuary in the United States), cert. denied, 498 U.S. 1046 (1991). Prosecution under U.S. law for speech crimes would raise issues quite different from those raised by U.S. judicial enforcement of a foreign judgment under foreign law. Cf. Matusevitch v. Telnikoff, 877 F. Supp. 1, 5 (D.D.C. 1995) (denying recognition to a U.K. libel judgment, partly on First Amendment grounds), aff'd on other grounds, 159 F.3d 636 (D.C. Cir. 1998); Paul Schiff Berman, Towards a Cosmopolitan Vision of Conflicts of Law: Redefining Governmental Interests in a Global Era, 153 U. PA. L. REv. 1819, 1821-22 (2005). 
extraterritorial location-either Guantanamo, or if that is not extraterritorial, then Diego Garcia. When I first wrote about these issues, extraterritorial criminal trials, prisons, and executions at Guantanamo seemed like an academic hypothetical, but that is no longer the case. Roosevelt's analysis appears to entail that the defendants would have no First Amendment rights to raise against such a prosecution.

Imposing criminal liability under U.S. law for core political speech of allied nationals in allied territory should be as constitutionally troubling as denying due process to suspected terrorists, which Roosevelt would condemn as a violation of extraterritorial Fifth Amendment rights. ${ }^{39}$ The mutuality of obligation approach (which is not currently the law) would extend First Amendment protection in this context. It is also very possible that Justice Kennedy's global due process approach would similarly extend protection, since I cannot identify anything "impracticable or anomalous" about respecting core political speech of allied nationals in allied territory.

Indeed, it is even possible that Roosevelt's conflict-of-laws approach would forbid some prosecutions for speech crimes, on Fifth Amendment rather than First Amendment grounds, if the censorship were so egregious that the Supreme Court would recoil from the conclusion that we are the "kind of a people [who] would do such a thing." dom of speech as we define it represents one of our fundamental values, but rather because some minimal level of respect for "the most basic rights of our alien friends" ${ }^{41}$ forms part of our self-image as a decent society. This conclusion is conceivable, but not certain. Perhaps extraterritorial censorship that bears a rational relationship to national defense is not so despotic as to offend this proposed interpretation of the Fifth Amendment.

To be sure, I have criticized the global due process approach for its lack of textual anchor and its unpredictability. But I am not able to see the varying answers that Professor Roosevelt's article gives to different constitutional provisions as evidencing a more consistent and predictable methodology either. Unfortunately, I suspect that this comes about because the field of conflict of laws is more in need of methodology than itself a source of methodology.

\footnotetext{
${ }^{39}$ See Roosevelt, supra note 2, at 2055-56.

${ }^{40} I d$. at 2068-69.

${ }^{41} I d$.
} 